\title{
The Consequences of Prior Initiation of Breast Feeding on Blood Glucose Levels in Neonates Born In a Tertiary Care Hospital
}

\author{
Rizwan-U-Zama ${ }^{\circledR 1}$, Ayesha Siddiqa ${ }^{\odot 2}$, A.N. Thobbi ${ }^{\oplus 3}$, Tehseen Sajid Mudhol ${ }^{\odot 4}$, R Shruthi ${ }^{\odot 2}$ \\ ${ }^{1}$ Assistant Professor, Department of Paediatrics, Al Ameen Medical College, Bijapur, Karnataka, India, ${ }^{2}$ Third Year PG, Department of Paediatrics, Al Ameen Medical \\ College, Bijapur, Karnataka, India, ${ }^{3}$ Professor, Department of Paediatrics, Al Ameen Medical College, Bijapur, Karnataka, India, ${ }^{4}$ MS, Department of OBG, Al Ameen \\ Medical College, Bijapur, Karnataka, India.
}

\section{Abstract}

Background: Hypoglycemia is the most common event of failure of metabolic adjustments in the newborn. Changes in maternal and fetal monitoring techniques, administration of glucose-containing solutions during labor, delivery and early feeding in neonates significantly alter blood glucose concentrations during the first week of postnatal life. Subjects and Methods: A total of 90 healthy (60 born by FTND, 30 born by LSCS) term, AGA infants were longitudinally evaluated at birth, at one hour after feeds (post feed), and after 6 hours of life. Plasma glucose was estimated from Heel Prick capillary samples by glucometer method. The influence of mode of delivery, the interval between feeds, sex, birth weight, on blood glucose was analyzed. Results: The way of delivery did not affect the plasma glucose concentration in neonates. There was a substantial increase in blood glucose concentration after the first feed irrespective of their birth weight. It was found that female babies had a higher blood glucose concentration than male babies during our study period. All babies maintained normal blood glucose with the continuation of breastfeeding. Conclusion: Plasma glucose levels are satisfactorily maintained in healthy term infants without resort to pre-lacteal feeds and mode of delivery did not influence plasma glucose. There is no need to check blood glucose levels routinely in an asymptomatic, healthy, term, breastfed infants.

Keywords: Glucose, Breastfeeding, Heel Prick capillary, delivery.

Corresponding Author: Rizwan-U- Zama, Assistant Professor, Department of Paediatrics, Al Ameen Medical College, Bijapur, Karnataka, India.

E-mail: rizwansholapurkar@gmail.com

Received: 12 May 2020

Revised: 14 June 2020

Accepted: 18 June 2020

Published: 9 July 2020

\section{Introduction}

Early initiation of breastfeeding within half an hour to one hour after birth is one of the essential ways to have successful feeding. ${ }^{[1,2]}$ If the feeding is started early, the dual benefits of colostrums and the budding relationship between mother and baby can be established. ${ }^{[3,4]}$ Considerable attention has been given to the adoption of internal feeding and its role in the prevention of hypoglycemia. ${ }^{[5,6]}$ Changes in maternal and fetal monitoring techniques, administration of glucose-containing solutions during labor and delivery and, early feeding in neonates significantly alter blood glucose concentrations during the first week of postnatal life. ${ }^{[7-9]}$ Hence this study is done to evaluate the blood glucose level in full-term neonates before and after the first breastfeed.

\section{Subjects and Methods}

A Prospective study of a total 90 healthy, term (37-41 weeks of gestational age) born at Al- Ameen medical college hospital, who weighed between $2.500 \mathrm{~kg}$ and $3.999 \mathrm{~kg}$, and were selected on simple random technique.

\section{Exclusion criteria}

1. Neonates of mothers with hurdles of pregnancy such as toxemia, anemia, diabetes, hypertension, prenatal infection, fetal distress, or use of any drugs during the last four weeks of pregnancy.

2. Mothers who had received dextrose containing fluids during labor and delivery

3. Neonates who had birth asphyxia, anoxia, respiratory distress, meconium staining, 5 minutes APGAR score < 7, polycythemia.

4. Congenital anomalies or intracranial hemorrhage 
5. Infants born by instrumental or breech delivery were also excluded from the study

Blood samples were taken by heelprick (capillary blood), the warmed foot being sufficiently vasodilated to allow free flow without compression.

The First sample was collected on the first day within 10 minutes of birth (pre-feed); the second sample was taken after one hour of feeding (post-feed), i.e., at one hour of age; the third sample was taken at 6th hour of life.

The estimation of blood glucose was done by using the glucose strip method. The results interpreted by the color change on the strip by visual and measured the value with a glucometer. We have compared the blood glucose values estimated by this method (glucose strip method) to the values determined by the conventional laboratory method before beginning the study and whenever doubts arose from this method on the study period. We found that there was a good correlation between the two ways.Immediately after the estimation of blood glucose within 10 minutes after birth (pre-feed), the baby was put to the breast for feeding in the labor room.

After 1 hour of feeding, the second sample of blood was estimated for the glucose level (post-feed)., At the end of 6 hours, the blood glucose levels were determined once again. Thus the blood glucose level was determined, one at pre-feed second, after one hour (post-feed), and third at the sixth hour of age.

\section{Materials Used}

- Glucometer System (Accutrend \pm Alpha, Rochediagnostics Gmb HD-68298 Mannheim, Germany

- Blood glucose strips - Accutrend \pm Alpha

- Lancet

- Dry cotton

- Weighing machine

\section{Results}

Ninety full-term infants (gestational age between 37-41 weeks) were included in this study. Sixty infants were delivered vaginally, and thirty infants by cesarean section as shown in [Table1].

The mean $( \pm \mathrm{SD})$ birth weight of the 60 neonates delivered by vaginally was $2.94 \pm 0.274 \mathrm{mg} / \mathrm{dL}$.

Range was $2.5-3.7 \mathrm{~kg}$. The mean gestational age was $38.05 \pm$ $0.723 \mathrm{mg} / \mathrm{dL}$, the mean $( \pm \mathrm{SD})$ APGAR score at 1 minute was $7.567 \pm 0.499$ and at 5 minutes was $8.75 \pm 0.436$. The mean \pm SD birth weight of the 30 neonates delivered by cesarean section was $3.126 \pm 0.32$ range was $2.5-3.75 \mathrm{~kg}$. The mean gestational age was $38.8 \pm 0.781$ weeks. The mean APGAR score at one minute was $7.467 \pm 0.507$ and at five minutes was $8.633 \pm 0.490$.

The Blood glucose values during the first 6 hours of life in full-term normal Delivery and LSCS as shown in [Table 2]

The mean $( \pm \mathrm{SD}$ ) blood glucose value for infants delivered by vaginally at birth was $79.9 \pm 11.579 \mathrm{mg} / \mathrm{dL}$ (pre-feed). The range was $36-102 \mathrm{mg} / \mathrm{dL}$. A significant rise occurred after the first feed, the mean increment at one hour being $11.48 \mathrm{mg} / \mathrm{dL}$ (mean blood glucose value at 1 hour of age was $91.383 \pm$ $10.984 \mathrm{mg} / \mathrm{dL})$ range was $57-116 \mathrm{mg} / \mathrm{dL}(\mathrm{p}<0.05)$. At $6^{\text {th }}$ hour of age, them ean blood glucose level was $67.01 \pm 7.40 \mathrm{mg} / \mathrm{dL}$ range was $52-88 \mathrm{mg} / \mathrm{dL}$.

The mean $( \pm$ SD) blood glucose value for infants delivered by LSCS at birth was $75.8 \pm 15.454 \mathrm{mg} / \mathrm{dL}$ (prefeed). The range was $38-102 \mathrm{mg} / \mathrm{dL}$. A significant rise occurred after the first feed, the mean increment at one hour being $10.36 \mathrm{mg} / \mathrm{dL}$, mean blood glucose value at 1 hour of age was $86.167 \mathrm{mg} / \mathrm{dL}$, which range from $50-118 \mathrm{mg} / \mathrm{dL}$. At the 6th hourof age, the mean blood glucose level was $69.267 \pm 12.068 \mathrm{mg} / \mathrm{dL}$.

The comparison of blood glucose levels in an infant born by LSCS \& vaginally as shown in [Table 3]

The mean $( \pm \mathrm{SD})$ blood glucose values in babies delivered by cesarean section at birth $(75.8 \pm 15.45 \mathrm{mg} / \mathrm{dL})$ were similar to those delivered by vaginally $(79.9 \pm 11.57 \mathrm{mg} / \mathrm{dL})$ range was $38-102 \mathrm{mg} / \mathrm{dL}$. At one hour of age, mean blood glucose values in cesarean section, babies were $86.167 \pm 16.80 \mathrm{mg} / \mathrm{dL}$ range was $50-118 \mathrm{mg} / \mathrm{dL}$ with a mean increment of $10.36 \mathrm{mg} / \mathrm{dL}$. After six hours of age, the mean blood glucose value was $69.267 \pm 12.06 \mathrm{mg} / \mathrm{dL}$. No significant difference was found between infants delivered by vaginally and cesarean section any time during the study period. ( $p>0.05$ )

The Mean blood glucose values concerned to birth weight as shown in [Table 4]

60 babies delivered vaginally were divided into 3 groups by birth weight 32 babies weighed 2.5 to $2.99 \mathrm{~kg}, 25$ babies weighed between 3.0 to $3.49 \mathrm{kgs}$ and 3 babies. Weighed between 3.5 to $3.99 \mathrm{kgs}$. Babies with birth weight between 2.5-2.99 kgs had a mean blood glucose level of $78.78 \pm 13.29$ $\mathrm{mg} / \mathrm{dL}$ at birth. After the first feed, at one hour of age the blood Glucose level rise to $91.218 \pm 11.732$, a mean increment being $12.438 \mathrm{mg} / \mathrm{dL}$. At six-hour of Age they showed mean blood glucose of $66.156 \pm 7.025 \mathrm{mg} / \mathrm{dL}$. The mean blood glucose value for Neonate, whose birth weight between $3.0-3.49 \mathrm{kgs}$ at birth was $81.12 \pm 9.879 \mathrm{mg} / \mathrm{dL}$. After the first Feed, at one hour of age, meanbloodglucoselevelwas $91.76 \pm 10.899 \mathrm{mg} / \mathrm{dL}$ with a mean Increment of $10.64 \mathrm{mg} / \mathrm{dL}$. After 6 hours of age, the blood glucose value was $67.76 \pm 8.14 \mathrm{mg} / \mathrm{dL}$.

Those babies who weighed 3.5 to $3.99 \mathrm{kghad}$ a blood glucose value of $82.00 \pm 0.00 \mathrm{mg} / \mathrm{dL}$ At birth, after one hour of age, the blood glucose value was $90.66 \pm 1.154 \mathrm{mg} / \mathrm{dL}$ with mean 
Table 1: Attributes of Patient Samples

\begin{tabular}{llll} 
& & $\begin{array}{l}\text { Full Term Normal Delivery } \\
\text { (FTND) (n=60) }\end{array}$ & LSC (n=30) \\
Birth weight (kgs) & & $2.94 \pm 0.2742$ & $3.1266 \pm 0.3281$ \\
Gestational age (weeks) & $1 \mathrm{~min}$ & $38.05 \pm 0.7231$ & $38.8 \pm 0.7811$ \\
APGAR score & $3 \mathrm{~min}$ & $7.567 \pm 0.499$ & $7.467 \pm 0.5074$ \\
& & $8.75 \pm 0.4366$ & $8.633 \pm 0.4901$ \\
\hline
\end{tabular}

Table 2: Blood Glucose Values During First 6 Hours of Life

\begin{tabular}{lllll}
\hline Groups & Age (hours) & Number of Samples & \multicolumn{2}{l}{ Blood glucose $(\mathbf{m g} / \mathbf{d L})$} \\
& & & Range & Mean \pm SD \\
\hline Full term normal & 0 & 60 & $36-102$ & $79.9 \pm 11.57919$ \\
& 1 & 60 & $57-116$ & $91.383 \pm 10.984$ \\
& 6 & 60 & $52-88$ & $66.93 \pm 7.5124$ \\
LSCS & 0 & 30 & $38-102$ & $75.8 \pm 15.454$ \\
& 1 & 30 & $50-118$ & $86.167 \pm 16.805$ \\
& 6 & 30 & $48-90$ & $69.267 \pm 12.068$ \\
\hline
\end{tabular}

\begin{tabular}{|c|c|c|c|c|}
\hline Age (hours) & Mode of Delivery & Number of samples & Mean & p-value \\
\hline \multirow[t]{2}{*}{0} & $\begin{array}{l}\text { Full Term Normal Delivery } \\
\text { (Ftnd) }\end{array}$ & 60 & $79.9 \pm 11.57$ & $>0.05$ \\
\hline & LSCS & 30 & $75.8 \pm 15.45$ & \\
\hline 1 & $\begin{array}{l}\text { Full Term Normal Delivery } \\
\text { (Ftnd) }\end{array}$ & 60 & $91.38 \pm 10.98$ & $>0.05$ \\
\hline \multirow[t]{2}{*}{6} & $\begin{array}{l}\text { Full Term Normal Delivery } \\
\text { (Ftnd) }\end{array}$ & 60 & $67.01 \pm 7.4$ & $>0.05$ \\
\hline & LSCS & 30 & $69.267 \pm 12.06$ & \\
\hline
\end{tabular}

Unpaired ' $\mathrm{t}$ ' test, $\mathrm{p}$ value $<0.05$ significant, $<0.001$ highly significant

$>0.05$ not significant

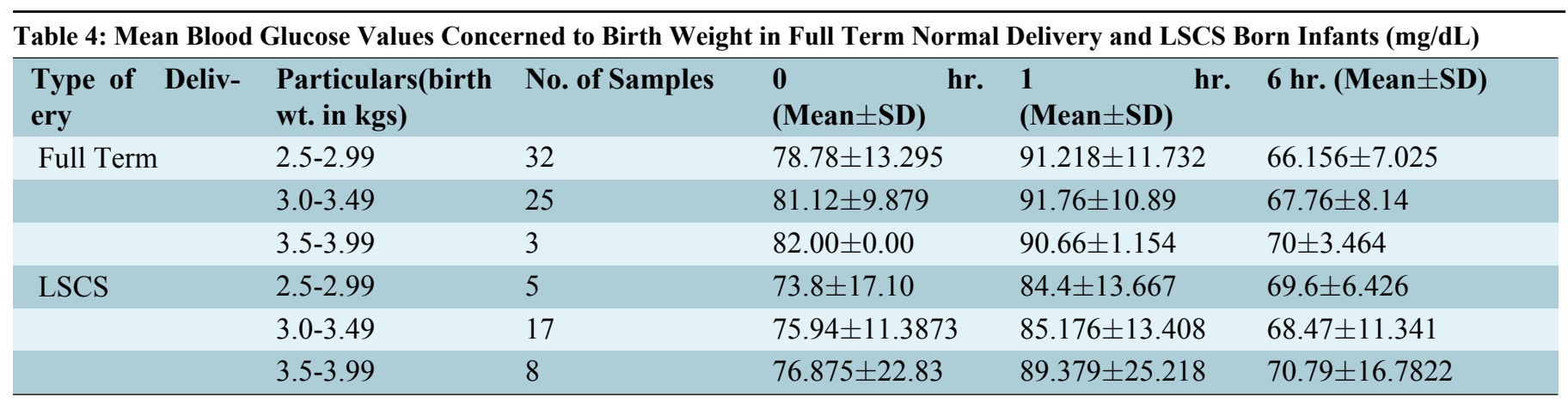




\begin{tabular}{|c|c|c|c|c|c|c|c|}
\hline $\begin{array}{l}\text { Birth } \\
\text { weight (in } \\
\text { kgs) }\end{array}$ & $\begin{array}{l}\text { Mode of } \\
\text { Delivery }\end{array}$ & $\begin{array}{l}\text { No. of sam- } \\
\text { ples }\end{array}$ & $\begin{array}{lr}\mathbf{0} & \text { hr. } \\
(\text { Mean } & \text { SD) }\end{array}$ & 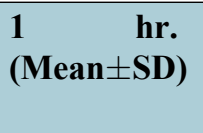 & $\begin{array}{l}6 r \\
(M e a n \pm S D)\end{array}$ & 't' value & p-value \\
\hline \multirow[t]{2}{*}{ 2.5-2.99 } & $\begin{array}{l}\text { Full Term } \\
\text { Normal } \\
\text { Delivery } \\
\text { (FTND) }\end{array}$ & 32 & $78.78 \pm 13.295$ & $91.218 \pm 11.7$ & $66.15 \pm 7.02$ & 1.12 & $\mathrm{p}>0.05$ \\
\hline & LSCS & 5 & $73.8 \pm 17.10$ & $84.4 \pm 13.66$ & $69.6 \pm 6.426$ & & \\
\hline \multirow[t]{2}{*}{$3-3.49$} & $\begin{array}{l}\text { Fullterm } \\
\text { Normal } \\
\text { eliv- } \\
\text { ery(FTND) }\end{array}$ & 25 & $81.12 \pm 9.87$ & $91.76 \pm 10.89$ & $67.76 \pm 8.14$ & 0.27 & $\mathrm{p}>0.05$ \\
\hline & LSCS & 17 & $75.94 \pm 11.382$ & $85.17 \pm 13.40$ & $68.47 \pm 11.34$ & & \\
\hline \multirow[t]{2}{*}{$3.5-3.99$} & $\begin{array}{l}\text { Full Term } \\
\text { Normal } \\
\text { Deliv- } \\
\text { ery(FTND) }\end{array}$ & 3 & $82.00 \pm 0.00$ & $90.66 \pm 1.154$ & $70 \pm 3.464$ & 0.069 & $\mathrm{p}>0.05$ \\
\hline & LSCS & 8 & $76.87 \pm 22.83$ & $89.379 \pm 25.2:$ & $70.79 \pm 16.78$ & & \\
\hline
\end{tabular}

Statistical analysis was by the unpaired ' $t$ ' $<0.05$ significant $p>0.05$ not significant

\begin{tabular}{|c|c|c|c|c|c|c|c|}
\hline Sex & $\begin{array}{l}\text { Type of } \\
\text { Delivery }\end{array}$ & $\begin{array}{l}\text { No. of sam- } \\
\text { ples }\end{array}$ & $\begin{array}{lr}\text { or } & \text { hr. } \\
(\text { Mean } & \text { SD })\end{array}$ & $\begin{array}{lr}1 & \text { hr. } \\
(\text { Mean } \pm \text { SD) }\end{array}$ & $\begin{array}{lr}6 & \text { hr. } \\
(\text { Mean } \pm \text { SD })\end{array}$ & 't' value & p-value \\
\hline \multirow[t]{2}{*}{ Male } & $\begin{array}{l}\text { Full Term } \\
\text { Normal } \\
\text { Delivery } \\
\text { (FTND) }\end{array}$ & 36 & $79.11 \pm 11.89$ & $90.55 \pm 11.3$ & $66.94 \pm 7.04$ & 0.13 & $\mathrm{p}>0.05$ \\
\hline & LSCS & 16 & $72.325 \pm 15.77$ & $82.62 \pm 17.61$ & $67.43 \pm 12.18$ & & \\
\hline \multirow[t]{2}{*}{ Female } & $\begin{array}{l}\text { Full Term } \\
\text { Normal } \\
\text { Delivery } \\
\text { (FTND) }\end{array}$ & 24 & $81.20 \pm 11.32$ & $93.166 \pm 11.32$ & $67.43 \pm 12.18$ & 1.01 & $\mathrm{p}>0.05$ \\
\hline & LSCS & 14 & $79.78 \pm 14.63$ & $91.78 \pm 14.63$ & $71.35 \pm 12.03$ & & \\
\hline
\end{tabular}

Statistical analysis was by the unpaired ' $\mathrm{t}$ ' test $\mathrm{p}<0.05$ significant $\mathrm{p}>0.05$ not significant

\begin{tabular}{|c|c|c|c|c|c|c|c|}
\hline Groups & Particulars & 0 hour & 1 hour & Diff. 0-1 & 6 hour & Diff. 1-6 & Diff. 0-6 \\
\hline \multirow[t]{4}{*}{ Full Term } & Mean & 79.9 & 91.38 & 11.48 & 67.01 & 24.45 & 13 \\
\hline & SD & 11.57 & 10.98 & - & 7.4 & - & - \\
\hline & ' $t$ ' value & - & - & 7.60 & - & 8.60 & 17.43 \\
\hline & 'p' value & - & - & $\mathrm{p}<0.05$ & - & $\mathrm{p}<0.05$ & $\mathrm{p}<0.05$ \\
\hline \multirow[t]{4}{*}{ LSCS } & Mean & 75.8 & 86.16 & 10.36 & 69.267 & 16.83 & 6.53 \\
\hline & SD & 15.45 & 16.80 & - & 12.06 & - & - \\
\hline & ' $t$ ' value & - & - & 3.67 & - & 2.31 & 5.99 \\
\hline & 'p' value & - & - & $\mathrm{p}<0.05$ & - & $\mathrm{p}<0.05$ & $\mathrm{p}<0.05$ \\
\hline
\end{tabular}

Statistical analysis was by the paired' test $\mathrm{p}<0.05$ significant; $\mathrm{p}>0.05$ not significant 
Increment of $8.66 \mathrm{mg} / \mathrm{dL}$. After 6 hours of age the blood glucose value was $70 \pm 3.464 \mathrm{mg} / \mathrm{dL}$.

Thirty babies delivered by LSCS were divided into three groups according to their birth weight. Five babies weighed between 2.5 to $2.99 \mathrm{~kg}, 17$ babies weighed between 3.0 to $3.49 \mathrm{kgs}$, and 8 babies were weigh in between 3.5 to $3.99 \mathrm{kgs}$.

Babies with birth weight between 2.5-2.99 kgs had a mean blood glucose level of $73.8 \pm 17.10 \mathrm{mg} / \mathrm{dL}$ at birth. After the first feed, at one hour of age, blood glucose level was $84.4 \pm$ $13.667 \mathrm{mg} / \mathrm{dL}$, a mean increment being $10.7 \mathrm{mg} / \mathrm{dL}$. At sixhour of age they showed a mean blood glucose value of 69.6 $\pm 6.426 \mathrm{mg} / \mathrm{dL}$. The mean blood glucose level for neonates, whose birth weight between 3.0 to $3.49 \mathrm{~kg}$ at birth was 75.94 $\pm 11.38 \mathrm{mg} / \mathrm{dL}$. After the first feed, at one hour of age, the mean blood glucose level was $85.176 \pm 13.40 \mathrm{mg} / \mathrm{dL}$ with a mean increment of $9.2 \mathrm{mg} / \mathrm{dL}$. After 6 hours of age the blood glucose level was $70 \pm 3.46 \mathrm{mg} / \mathrm{dL}$.

Infants who were weighing between 3.5 to $3.99 \mathrm{kgs} \mathrm{had} \mathrm{a} \mathrm{blood}$ glucose level of $76.875 \pm 22.83 \mathrm{mg} / \mathrm{dL}$ at birth. After one hour of age, the blood glucose value was $85.176 \pm 13.408 \mathrm{mg} / \mathrm{dL}$ with a mean increment of $8.30 \mathrm{mg} / \mathrm{dL}$. After 6 hours of age, the blood glucose value was $70.79 \pm 16.78 \mathrm{mg} / \mathrm{dL}$. The mean blood glucose levels concerned with weight as shown in [Table 5].

A significant rise in the mean blood glucose level occurred in each group after the first feed $(\mathrm{p}<0.05)$, however newborns with birth weight between 2.5 to $2.99 \mathrm{~kg}$ were shown maximum increment in the rise of blood glucose level as occurred with FTND babies. Although no significant difference was found between each group (FTND and LSCS), the mean increment of blood glucose level after the first feed $(\mathrm{p}>0.05)$. From this result, it was found that mean blood glucose value increases as the birth weight of the newborns' increases. No statistically significant difference in blood glucose level was found at 6th hour of age in all the groups. The mean blood glucose levels in comparison to sex, as shown in [Table 6].

36 of 60 babies delivered vaginally were males, and 24 were females. It was found that mean blood glucose value for females at birth was $81.20 \pm 11.32 \mathrm{mg} / \mathrm{dL}$ as compared to male babies whose mean blood glucose value was $79.11 \pm$ 11.89. After one hour of age, the mean blood glucose value for female babies was $93.16 \pm 11.32$ as compared to male babies, $90.55 \pm 11.3 \mathrm{mg} / \mathrm{dL}$. After 6 hours of life, mean blood glucose value for females was $67.25 \pm 7.04 \mathrm{mg} / \mathrm{dL}$ compared to male babies, a blood glucose value $66.94 \pm 7.69 \mathrm{mg} / \mathrm{dL} .16$ babies born by LSCS were male. Mean blood glucose value sat birth was $72.32 \pm 15.77 \mathrm{mg} / \mathrm{dL}$ and the female baby's mean blood glucose value was $79.78 \pm 14.63 \mathrm{mg} / \mathrm{dL}$. After one hour of feed, the mean blood glucose value was $82.62 \pm 17.61 \mathrm{mg} / \mathrm{dL}$ in male babies and in female babies mean blood glucose value was $91.00 \pm 12.01 \mathrm{mg} / \mathrm{dL}$. After 6 hours of age, the mean blood glucose value was $67.43 \pm 12.18 \mathrm{mg} / \mathrm{dL}$ in Male babies, and in female babies, it was $71.35 \pm 12.03 \mathrm{mg} / \mathrm{dL}$.

From this study, it is found that mean blood glucose values were higher in female babies both in FTND and LSCS born babies throughout our study period, but statistically was not significant $(\mathrm{p}>0.05)$.

In this study, one baby born by FTND had a blood glucose value of $36 \mathrm{mg} / \mathrm{dL}$ at birth. One baby born by LSCS had a blood glucose value of $38 \mathrm{mg} / \mathrm{dL}$ at birth. Both these babies were asymptomatic. These babies were given breastfeeds frequently. They maintained blood glucose levels with additional breastfeeding. The comparison of blood glucose levels at different time intervals, as shown in [Table 7].

\section{Discussion}

Hypoglycemia is an essential complication in the newborns, initiation of early feeding has immense value in safeguarding against hypoglycemia. ${ }^{[10,11]}$

Organizations like WHO, UNICEF and Breastfeeding Promotion Network of India (BPNI) are working hard for the last few years to promote exclusive breastfeeding in newborns and encourage the establishment of baby-friendly hospitals all over the world. ${ }^{[12,13]}$ The comparison of mean blood glucose levels in infants born by vaginally \& cesarean section, as shown in [Table 8].

In our study, the mean blood glucose values of female babies were slightly higher than the male babies delivered by FTND and LSCS. The incidence of healthy term infants with blood glucose levels in various studies14as shown in [Table 9].

In our study, 2 babies (2.2\%) (One from Full Term Normal Delivery group and the other baby from LSCS group) had blood glucose concentration below $40 \mathrm{mg} / \mathrm{dL}$. As these babies were asymptomatic, they were given breastfeeding. After 1 hour of breastfeeding, their blood glucose values were normal. With demand feeding, all babies maintained normal glucose levels throughout our studyperiod. The results of our study confirmed that the early initiation of breastfeeding i.e. colostrum increases the blood glucose level within one hour, and euglycemic state was maintained by continuing breastfeeds in infants irrespective of their birth weight, type of delivery and sex of the babies. ${ }^{[14]}$

\section{Conclusion}

Plasma glucose levels are satisfactorily maintained in healthy term infants without resort to pre-lacteal feeds and mode of delivery did not influence plasma glucose. There is no need 


\begin{tabular}{|c|c|c|c|c|c|}
\hline Age (hours) & $\begin{array}{l}\text { No. of } \\
\text { Samples }\end{array}$ & Mode of Delivery & Hawdonet al.27 & $\begin{array}{l}\text { Diwakar et al. } \\
.47\end{array}$ & Present Study \\
\hline \multirow{2}{*}{ Birth } & & Normal delivery & 4.3 & - & 4.43 \\
\hline & & LSCS & 3.4 & - & 4.21 \\
\hline \multirow[t]{2}{*}{1 hour } & & Normal Delivery & 3.1 & - & 5.07 \\
\hline & & LSCS & 3.3 & - & 4.78 \\
\hline \multirow[t]{2}{*}{2 hour } & & Normal Delivery & - & - & - \\
\hline & & LSCS & - & - & - \\
\hline \multirow[t]{2}{*}{3 hour } & & Normal Delivery & - & 3.01 & - \\
\hline & & LSCS & - & 3.0 & - \\
\hline \multirow[t]{2}{*}{6 hour } & & Normal Delivery & - & 2.88 & 3.71 \\
\hline & & LSCS & - & 3.00 & 3.84 \\
\hline \multirow[t]{2}{*}{$12-24$ hour } & & Normal Delivery & 3.7 & - & - \\
\hline & & LSCS & 3.3 & - & - \\
\hline \multirow[t]{2}{*}{24 hour } & & Normal Delivery & - & 2.83 & - \\
\hline & & LSCS & - & 2.92 & - \\
\hline
\end{tabular}

Table 9: Incidence of Healthy Term Infants with a Blood Glucoseconcentration below Certain Cut Offs in Different Studies

\begin{tabular}{|c|c|c|c|c|}
\hline & $\begin{array}{l}\text { Glucose Concentra- } \\
\text { tion }(\mathrm{mmol} / \mathrm{L})\end{array}$ & Incidence & $\begin{array}{l}\text { Hours of study after } \\
\text { delivery }\end{array}$ & Study Design \\
\hline $\begin{array}{l}\text { Srinivasan et al.39 } \\
(1986)\end{array}$ & $<2$ (plasma) & $2 \%$ & 3 hours & Longitudinal \\
\hline $\begin{array}{l}\text { Heck \& Erenberg40 } \\
\text { (1987) }\end{array}$ & $<1.8$ (blood) & $8 \%$ & 48 hours & Longitudinal \\
\hline $\begin{array}{l}\text { Hawdon et al.27 } \\
(1992)\end{array}$ & $<2.6$ (blood) & $12 \%$ & 96 hours & Cross sectional \\
\hline $\begin{array}{l}\text { Cole \& Peevy61 } \\
(1994)\end{array}$ & $<2.2$ (blood) & $40 \%$ & 2 hours & \\
\hline Tanzer et al.62 (1997) & $<1.8$ (blood) & $34 \%$ & 48 hours & Longitudinal \\
\hline Hoseth et al.46 (2000) & $\begin{array}{l}<2.2 \text { (blood) }< \\
2.6 \text { (blood) }\end{array}$ & $4 \% 14 \%$ & 96hours 96hours & Cross- sectional \\
\hline $\begin{array}{l}\text { Nicholl R. et al.48 } \\
(2003)\end{array}$ & $<2.6$ (blood) & $12-14 \%$ & 72 hours & Longitudinal \\
\hline $\begin{array}{l}\text { The present study } \\
(2005)\end{array}$ & $\begin{array}{l}<2.2 \text { (blood) } \quad(40 \\
\mathrm{mg} / \mathrm{dL})\end{array}$ & $2.2 \%$ & 6 hours & Longitudinal \\
\hline
\end{tabular}

to check blood glucose levels routinely in an asymptomatic, healthy, term, breastfed infants.

\section{References}

1. Karim F, Billah SM, Chowdhury MAK, Zaka N, Manu A, Arifeen SE. Initiation of breastfeeding within one hour of birth and its determinants among normal vaginal deliveries at primary and secondary health facilities in Bangladesh: A caseobservation study. PLoS One. 2018;13(8):e0202508. Available from: https://dx.doi.org/10.1371/journal.pone.0202508.

2. Ghimire U. The effect of maternal health service utilization in early initiation of breastfeeding among Nepalese mothers. Int Breastfeed J. 2019;14:33. Available from: https:// dx.doi.org/10.1186/s13006-019-0228-7. doi:10.1186/s13006019-0228-7.

3. Lucas A, Morley R, Cole TJ. Adverse neurodevelopmental outcome of moderate neonatal hypoglycaemia. Br Med J. 1988;297(6659):1304-1308. Available from: https://dx.doi. org/10.1136/bmj.297.6659.1304. 
4. Sharma N, Sur BK, Sukla R. A simplified technique for estimation of blood glucose level in the newborn from birth to 7 days. Indian J Pediatr. 1978;45:11-17. Available from: https://dx.doi.org/10.1007/BF02749456.

5. Wilkins BH, Kalra D. Comparison of blood glucose test strips in the detection of neonatal hypoglycaemia. Arch Dis Child. 1982;57(12):948-950. Available from: https://dx.doi.org/10. 1136/adc.57.12.948.

6. Perelman RH, Gutcher GR, Engle M, Donald MJ. Comparative analysis of four methods for rapid glucose determination in neonates. Am J Dis Child. 1982;136:10511053. Available from: https://dx.doi.org/10.1001/archpedi. 1982.03970480017003.

7. L S, M S. The yield and nutrient content of colostrum and milk of women from giving birth to 1 month post-partum. Br J Nutr. 1984;52(1):87-95. Available from: https://dx.doi.org/10.1079/ bjn19840074.

8. Bhalla M, Srivastava JR, Bhalla JN, Sinha DN, Sur BK. A study of blood glucose level in the newborn-From birth to 7 days. Indian J Pediatr. 1978;45(1):11-17. Available from: https://dx.doi.org/10.1007/bf02749456.

9. Cole PK. Hypoglycemia in term neonatesappropriate for gestational age. J Perinatol. 1994;14(2):118-120.

10. Tanzer F, Yazar N, Yazar H, İçağasioğlu D. Blood Glucose Levels and Hypoglycaemia in Full Term Neonates During the First 48 Hours of Life. J Trop Pediatr. 1997;43(1):58-60. Available from: https://dx.doi.org/10.1093/tropej/43.1.58-a.

11. Stoll BJ, M R. The high-risk infant: Assessment of gestational age at birth. In: Kliegman, Jenson, et al., editors. Nelson
Textbook of Pediatrics; 2004. p. 551-552.

12. Stanley CA, Baker L. The Causes of Neonatal Hypoglycemia. New Engl J Med. 1999;340(15):1200-1201. Available from: https://dx.doi.org/10.1056/nejm199904153401510.

13. Aziz K, Dancey P, and. Screening guidelines for newborns at risk for low blood glucose. Paediatr Child Health. 2004;9:723729. Available from: https://dx.doi.org/10.1093/pch/9.10.723.

14. E H, A J, Ebbesen F, Moeller M. Blood glucose levels in a population of healthy, breast fed, term infants of appropriate size for gestational age. Arch Dis Child Fetal Neonatal Ed. 2000;83(2):117-119. Available from: https://dx.doi.org/10. 1136/fn.83.2.f117.

Copyright: (C) the author(s), 2020. It is an open-access article distributed under the terms of the Creative Commons Attribution License (CC BY 4.0), which permits authors to retain ownership of the copyright for their content, and allow anyone to download, reuse, reprint, modify, distribute and/or copy the content as long as the original authors and source are cited.

How to cite this article: Zama RU, Siddiqa A, Thobbi AN, Mudhol TS, Shruthi R. The Consequences of Prior Initiation of Breast Feeding on Blood Glucose Levels in Neonates Born In a Tertiary Care Hospital. Asian J. Clin. Pediatr. Neonatol. 2020; 8(2):23-29.

DOI: dx.doi.org/10.47009/ajcpn.2020.8.2.5

Source of Support: Nil, Conflict of Interest: None declared.

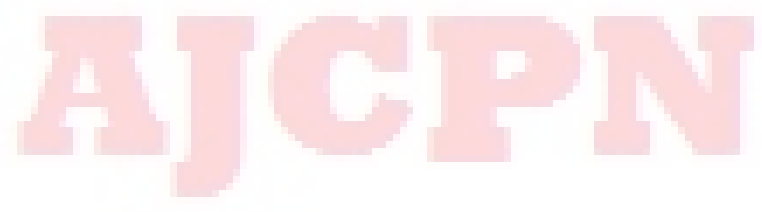

